\title{
The Chronostratigraphic Nomenclatorial History of the Pennsylvanian: \\ Series to System to Subsystem
}

Noah Morris

Dr. Walter L. Manger

South-Central GSA Meeting

March 12, 2018

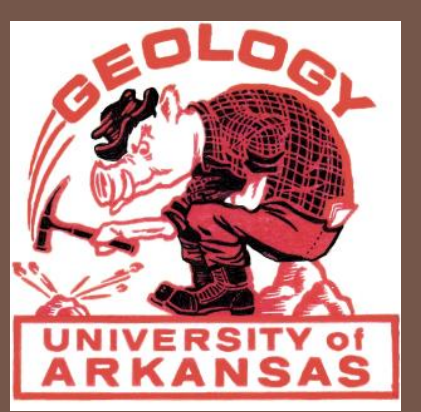




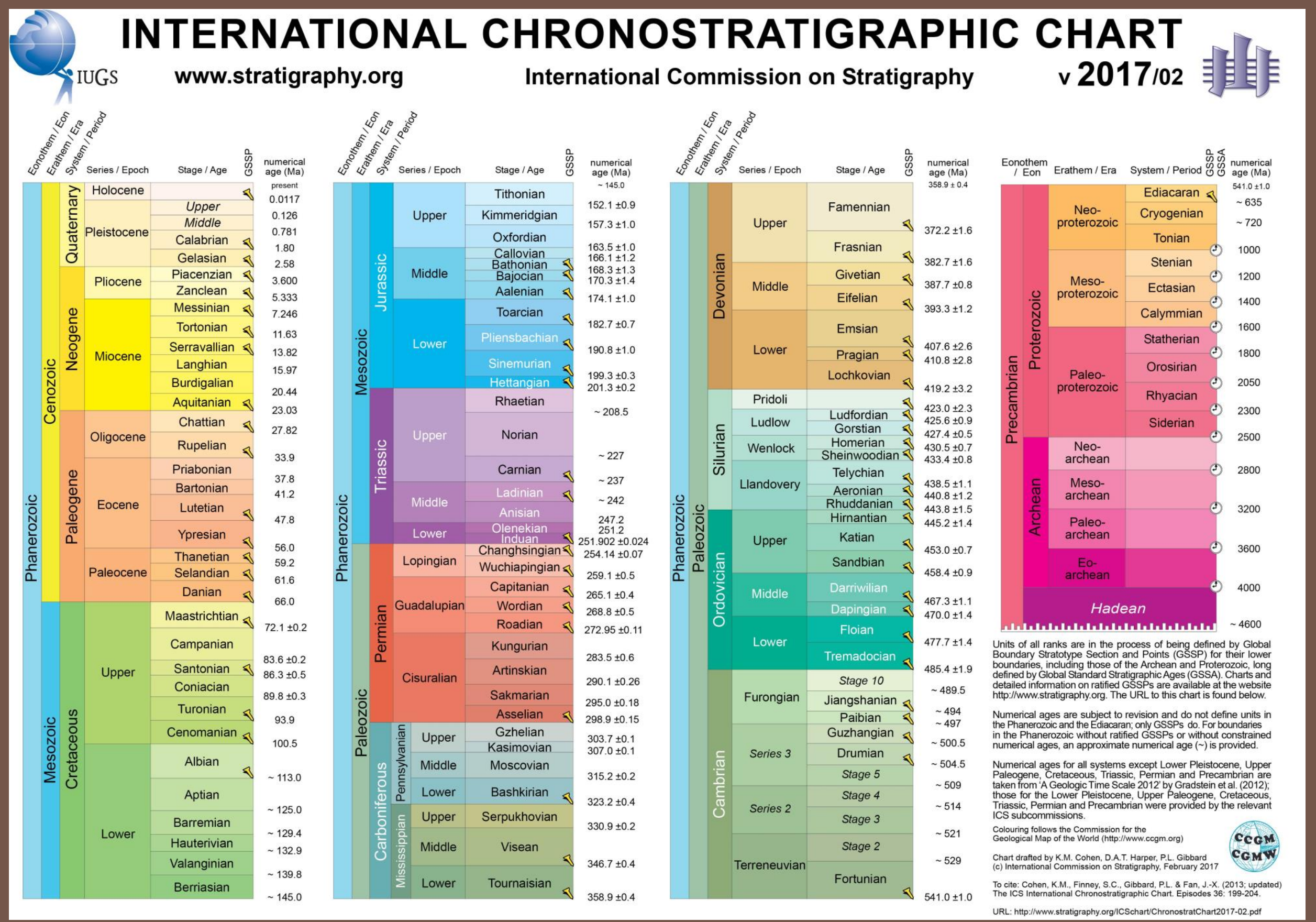




\section{European Stratigraphy}

\begin{tabular}{|c|c|c|c|}
\hline Character & Proposed names & Wernerian names & Other writers \\
\hline $\begin{array}{l}\text { 1. Formations (chiefly of sand \& clay) } \\
\text { above the chalk. }\end{array}$ & Superior order. & Newest flœtz class. & Tertiary class. \\
\hline $\begin{array}{l}\text { 2. Comprising } \\
\text { a. Chalk. } \\
\text { b. sands \& clays beneath the chalk. } \\
\text { c. calcareous freestones (oolites), \& } \\
\text { argillaceous beds. } \\
\text { d. New red sandstone, conglomerate \& } \\
\text { magnesian limestone. }\end{array}$ & Supermedial order. & Flœtz class. & Secondary class. \\
\hline $\begin{array}{l}\text { 3. Carboniferous rocks, comprising } \\
\text { a. Coal-measures. } \\
\text { b. Carboniferous limestone. } \\
\text { c. Old red sandstone. }\end{array}$ & Medial order. & \multicolumn{2}{|c|}{$\begin{array}{l}\text { Sometimes referred to the preceding } \\
\text { sometimes to the succeeding class by } \\
\text { writers of these schools; very of ten the } \\
\text { coal-measures are referred to the former } \\
\text { - the subjacent limestone and sand- } \\
\text { stone to the latter. }\end{array}$} \\
\hline 4. Roofing slate, \&c. \& c. & Submedial order. & Transition class. & Intermediate class. \\
\hline $\begin{array}{l}\text { 5. Mica slate. } \\
\text { Gneiss. } \\
\text { Granite, \& c. }\end{array}$ & Inferior order. & Primitive class. & Primitive class. \\
\hline
\end{tabular}

Conybeare and Phillips, 1822, p. vii 


\section{North American Stratigraphy}

Mid- to late-1800s:

Increase in coal production

Several geological surveys and university geologists study coal

Various stratigraphic nomenclatures in use for the "Coal Measures" of the Carboniferous 


\section{$19^{\text {th }}$ Century}

1883: Edward Orton Sr., the State Geologist of Ohio, writes a paper titled "The Lower Coal Measures of Ohio," and notes nomenclature problems between state surveys

Proposes using the "Pennsylvania System" for the Ohio stratigraphic units

i.e. the system of nomenclature used by the Pennsylvanian Geological Survey

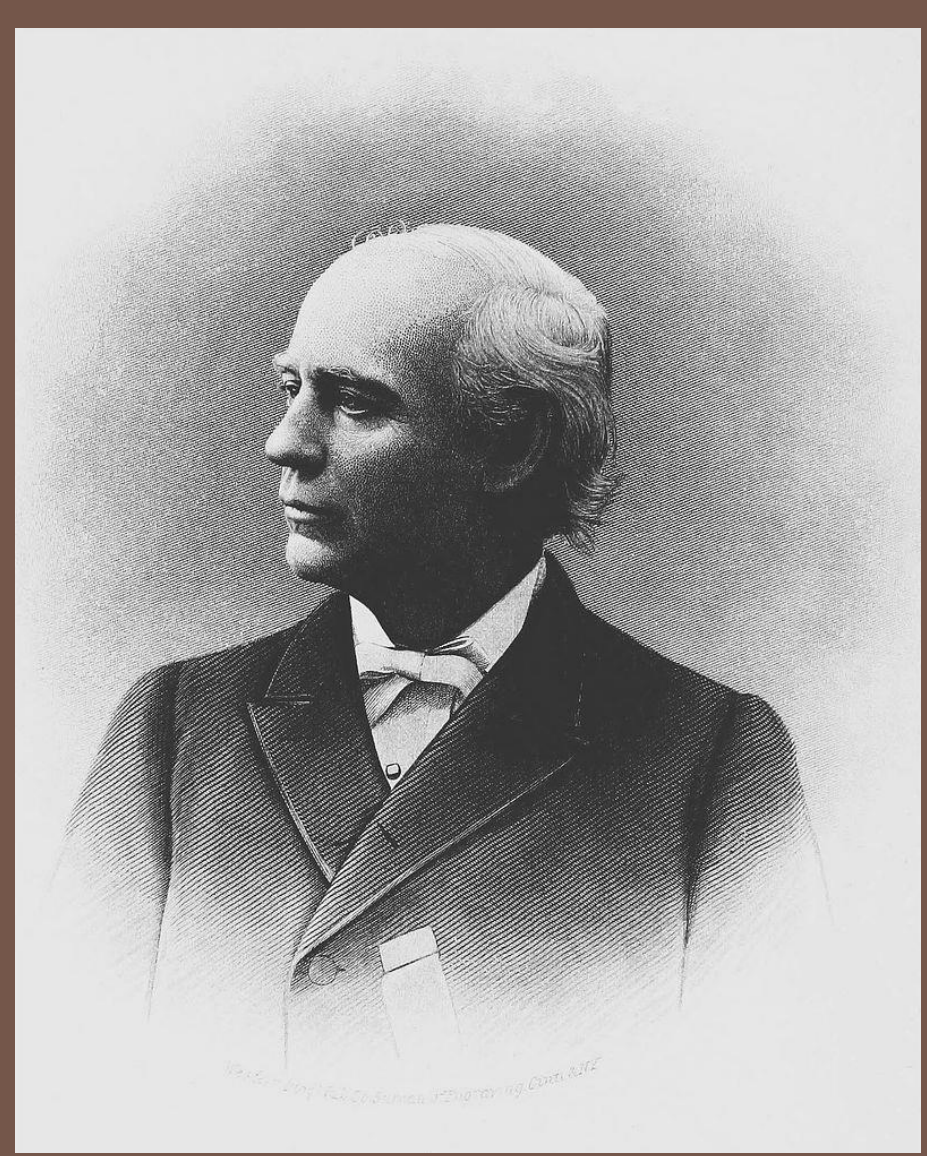

Wikimedia Commons 


\section{$19^{\text {th }}$ Century}

1889: USGS holds a conference to resolve nomenclatorial problems and to begin preparation of A Geologic Atlas of the United States

Adopts the Carboniferous Period

Use "system" as a separate stratigraphic term 


\section{$19^{\text {th }}$ Century}

1891: "Pennsylvanian series" as chronostratigraphic term

Henry Shaler Williams writes in USGS Bulletin 80:

Table of Contents -

Chaptrr V. The Coal Measures or Pennsylvanian series: The development of

its nomenclature and classification in the Appalachian Province (1836-1888).

Chapter 4 Title -

\section{CH A P T E R I V.}

THE COAL MEASURES OR PENNSYLVANIA SERIES. THE DEVELOPMENT OF ITS NOMENCLATURE AND CLASSIFICATION IN THE APPALACHIAN PROVINCE. 


\section{$19^{\text {th }}$ Century}

1891: J.C. Branner, State Geologist of Arkansas, publishes a stratigraphic chart citing Williams for both the Mississippian and Pennsylvanian Series name
THE FORMATIONS OF WASHINGTON COUNTY.

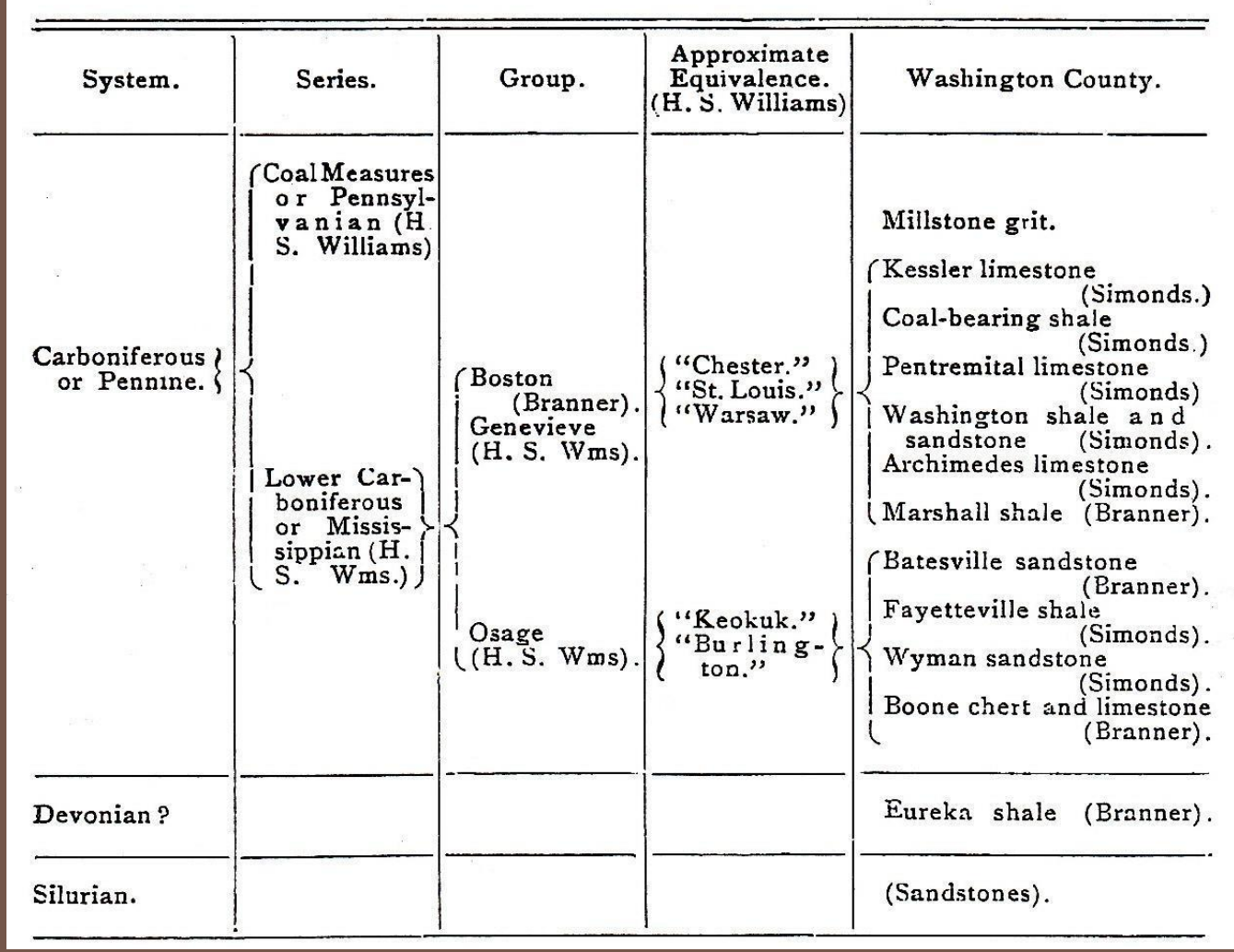

Branner, 1891, p. xiii 


\section{Pennsylvanian Author}

Some credit John James Stevenson (1888) for proposing the

Pennsylvanian System

Gradstein, et al., 2004

Gradstein, et al., 2012

Richards, 2012

Humbold University website, 2014

Unclear as to why this is

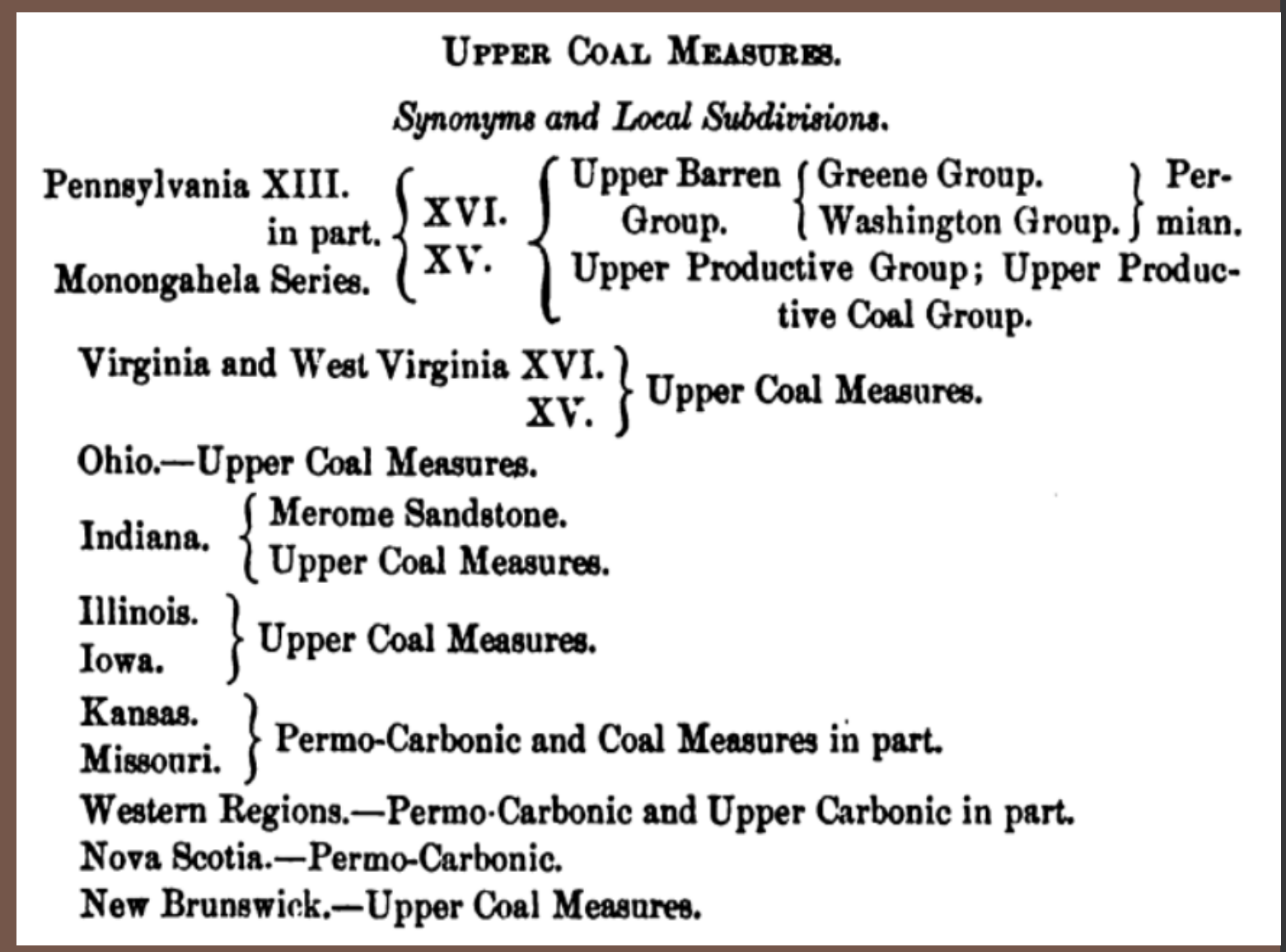

Stevenson, 1888, p. D4 


\section{Pennsylvanian Author}

Stevenson (1907) cites Williams as author

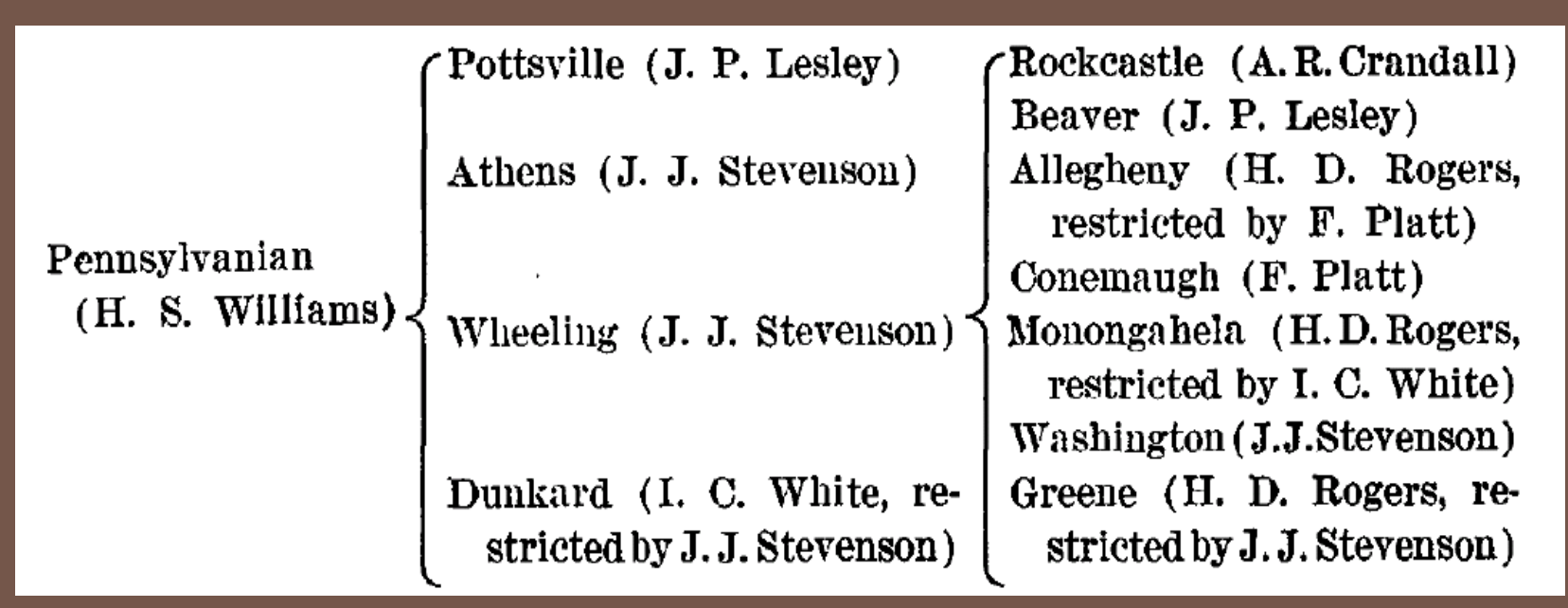

Stevenson, 1907, p. 178 


\section{$20^{\text {th }}$ Century}

Increase in natural resource production in early 1900s

Post-WWI years: National Academy of Sciences establishes subcommittees on the Mississippian and Pennsylvanian stratigraphy

Post-WWII years: GSA and AAPG later begin own subcommittees

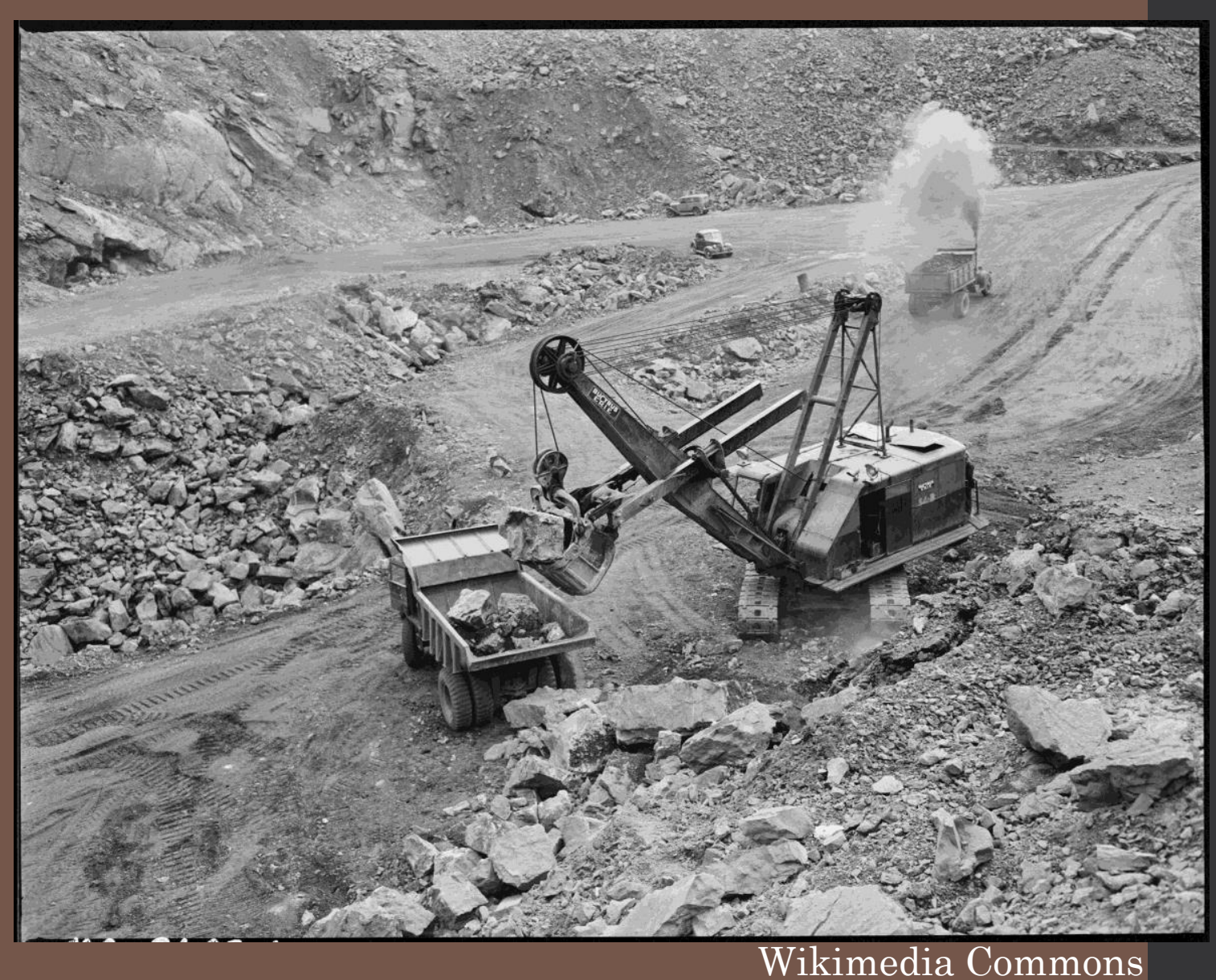




\section{$20^{\text {th }}$ Century}

1924: USGS adopts the Mississippian and Pennsylvanian as "series" within the Carboniferous Period

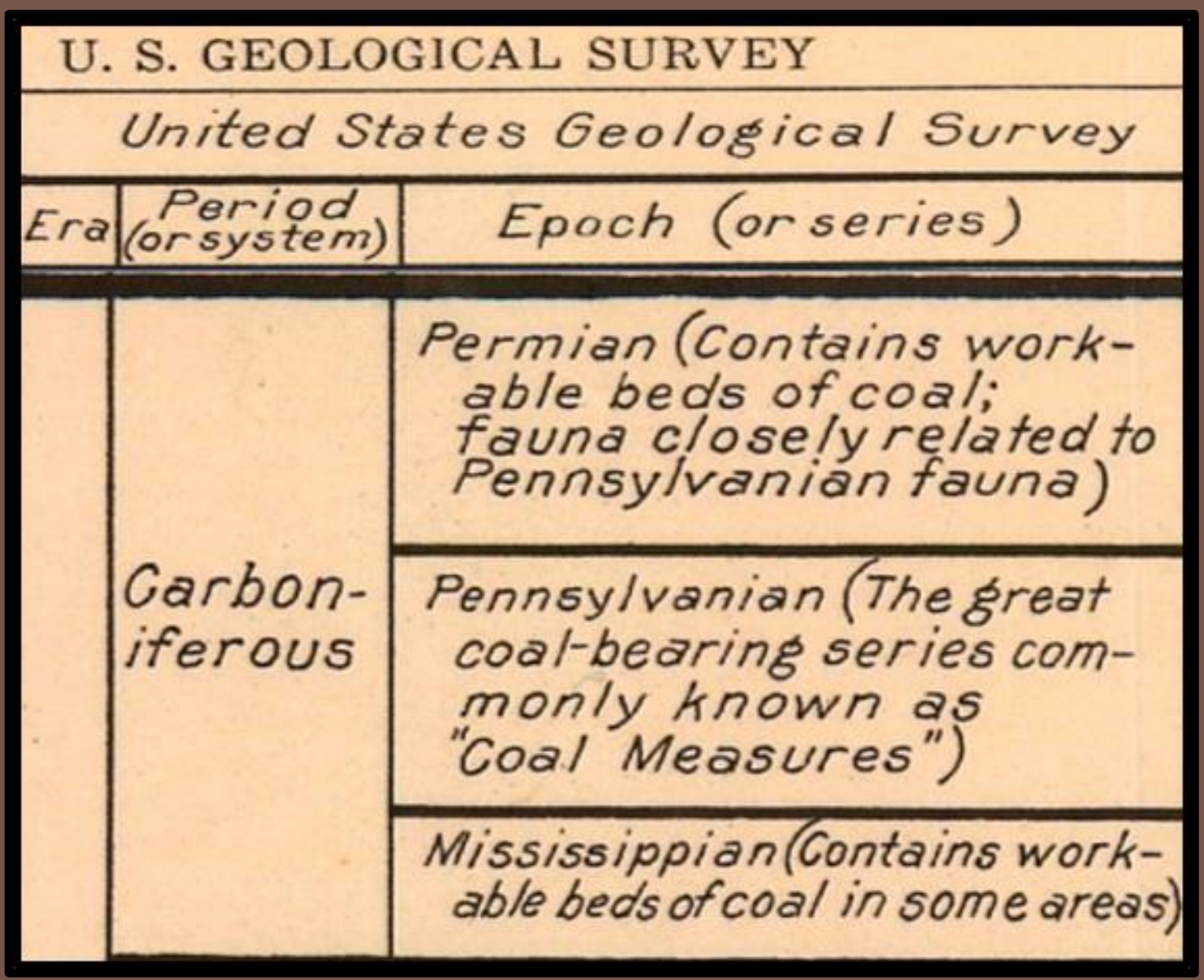

Wilmarth, 1924, published 1925 


\section{$20^{\text {th }}$ Century}

1953: USGS elevates the Mississippian and Pennsylvanian to "systems"

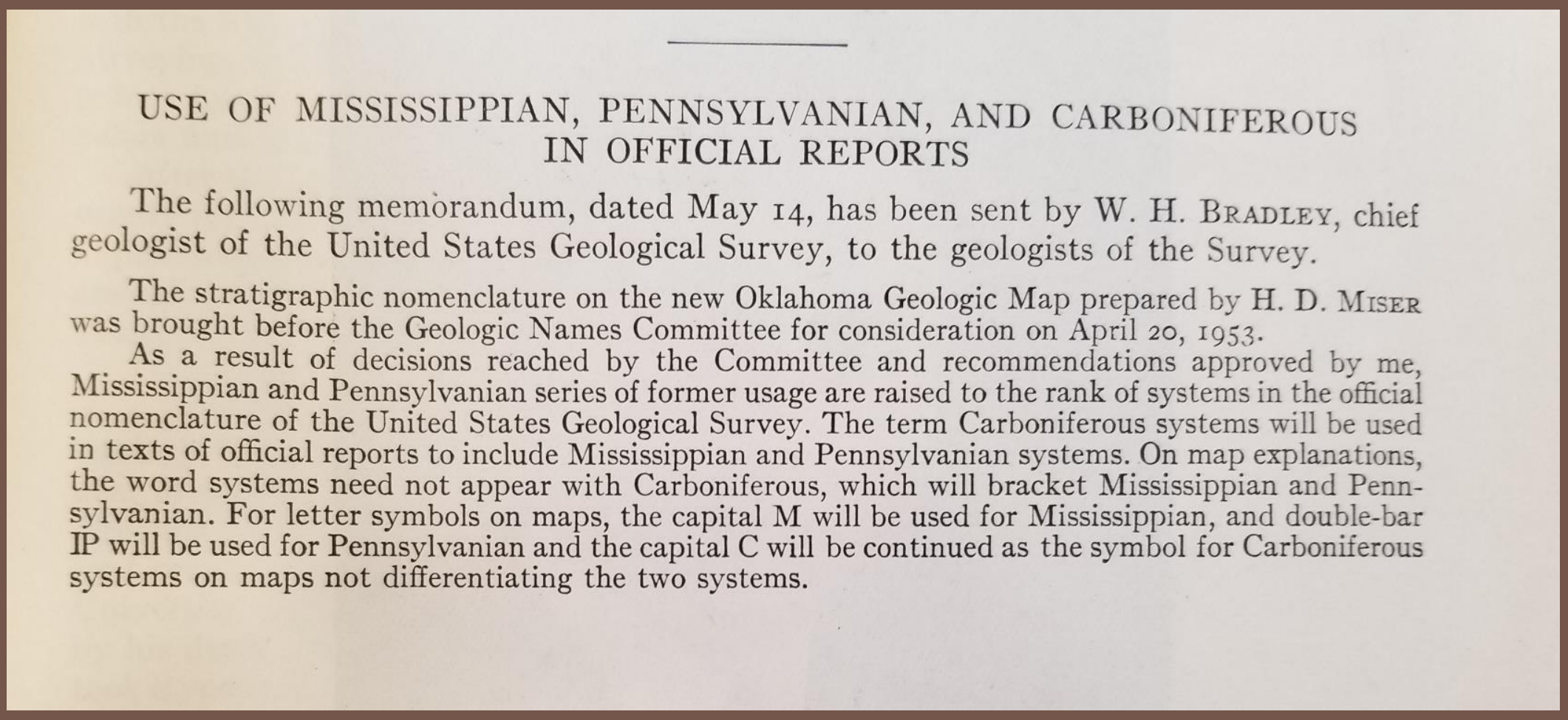

Bradley, 1953 


\section{$20^{\text {th }}$ Century}

1956: USGS memo reminding that the Mississippian and Pennsylvanian are "systems"

USE OF SERIES SUBDIVISIONS OF THE MISSISSIPPIAN

AND PENNSYLVANIAN SYSTEMS IN REPORTS BY

MEMBERS OF THE U. S. GEOLOGICAL SURVEY ${ }^{1}$

W. H. BRADLEY?

Washington, D. C.

Pennsylvanien syslem

1. In the Appalachian region, Lower, Middle, and Upper Pennsylvanian will be used. The division between Lower and Middle Pennsylvanian is at the top of the New River and equivalent rocks and the division between Middle and Upper Pennsylvanian is at the approximate boundary between the Allegheny and the Conemaugh.

2. In the Mid-Continent region (including Arkansas, Iowa, Kansas, Missouri, Nebraska, and Oklahoma), Morrow, Atoka, Des Moines, Missouri, and Virgil series will be used.

3. In other areas, Lower, Middle, and Upper Pennsylvanian will be used. These series in marine sections are approximate equivalents of the corresponding series Lower. Middle, and Upper of the Appalachian region; and Lower is equivalent to the Morrow, Middle to the Atoka and Des Moines, and Cpper to the Missouri and Virgil of the Mid-Continent region.

This action does not change the classification of Carboniferous systems used in the official nomenclature to include Mississippian system and Pennsylvanian system, as provided for in my memorandum of May 14, $1953 .{ }^{3}$

a "Use of Mississippian, Pennsylvanian, and Carboniferous in Official Reports," Bull. .t mer. Assic., Petrol. Geol., Vol. 37, No. 6 (June, 1953), p. 1533. 


\section{$21^{\text {st }}$ Century}

2004: Int'1 Committee on Stratigraphy establishes the Mississippian and

Pennsylvanian as global "Subsystems" of the Carboniferous System

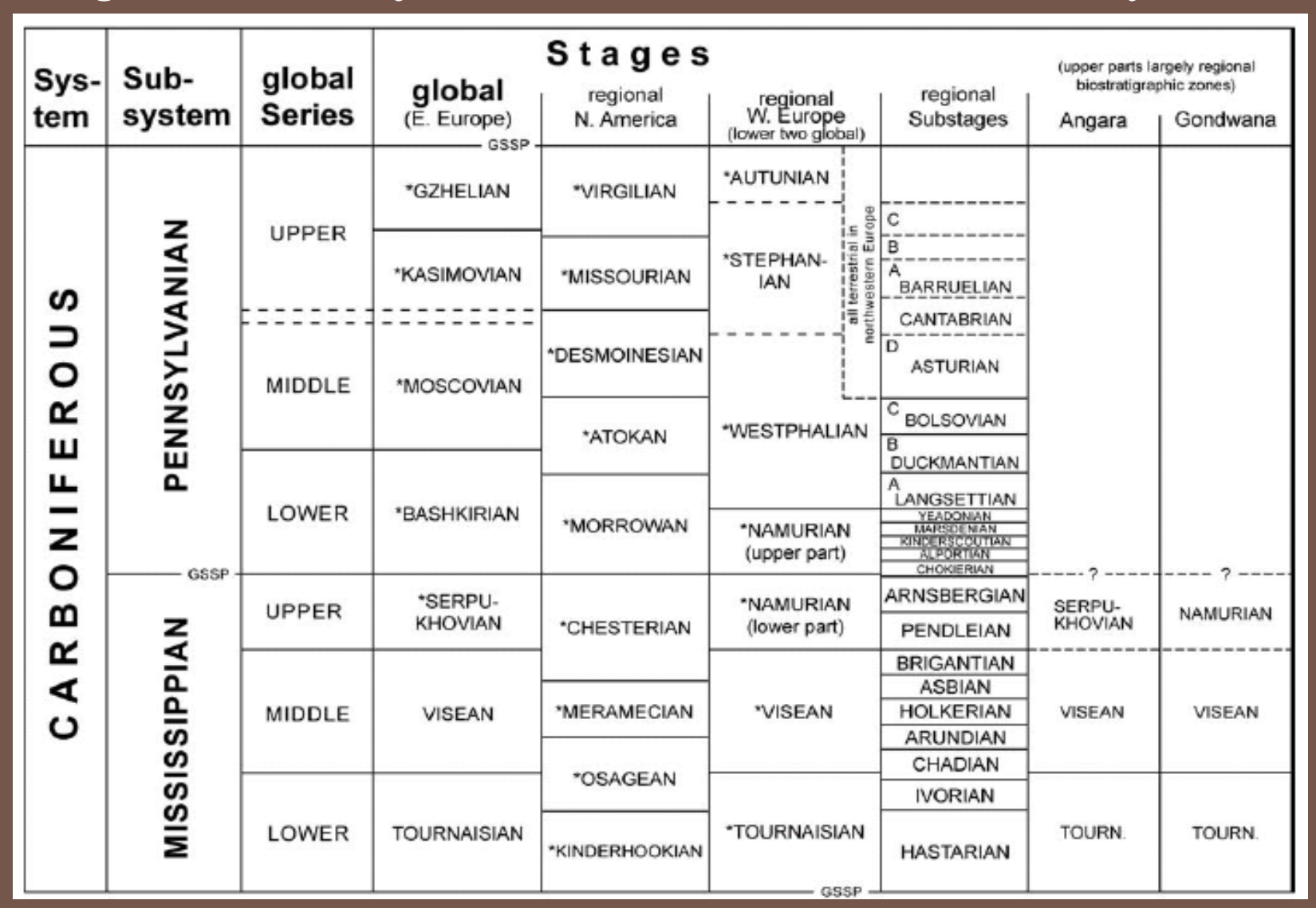




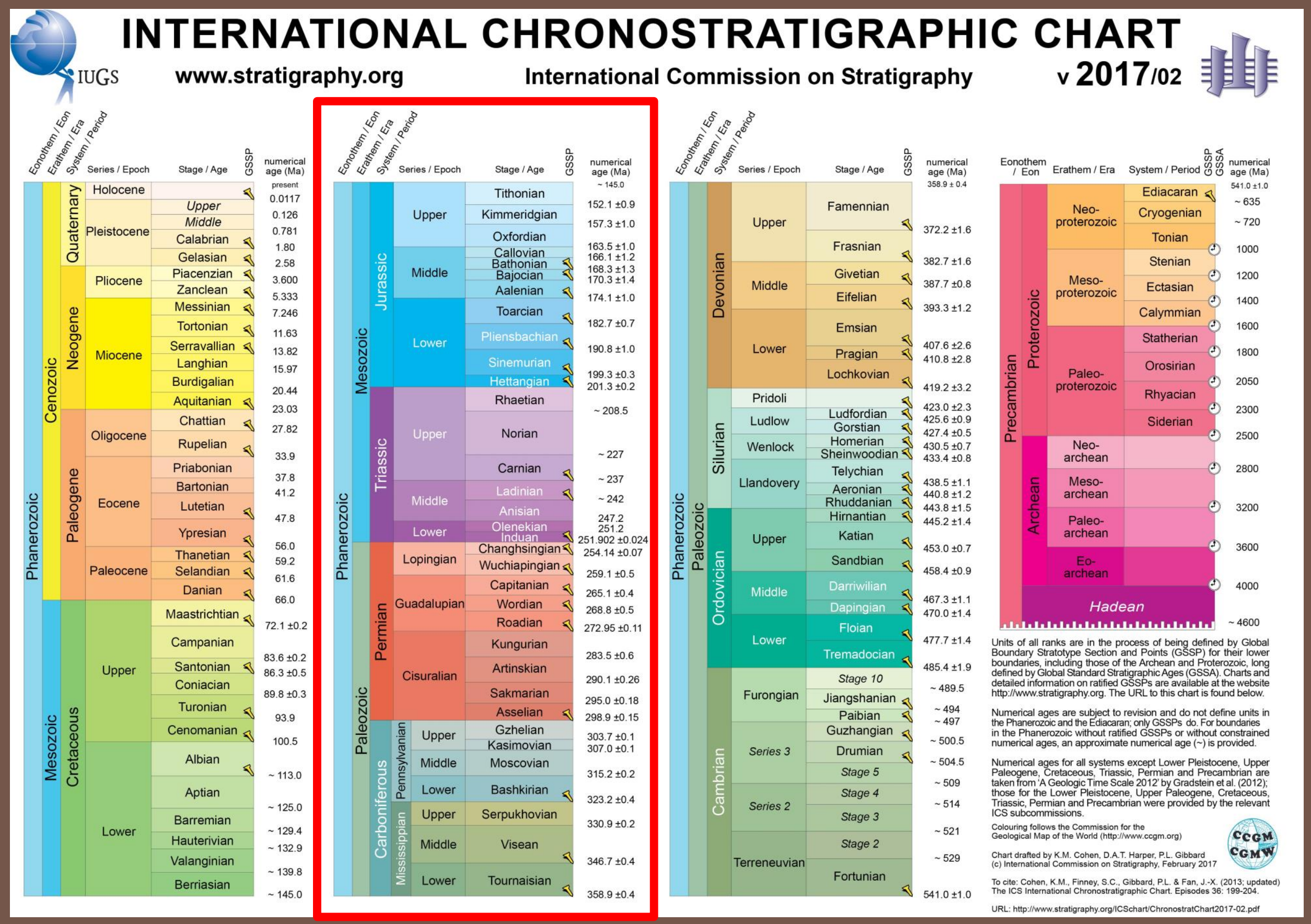




\section{References}

Arduino, Giovanni, 1760. Due lettere del sig. Giovanni Arduino sopra varie sue osservazioni naurali. Nuova Raccolta d’Opuscoli Scientifici e Filologici, 6. p. 97-180.

Bradley, J., 1953, Use of Mississippian, Pennsylvanian, and Carboniferous in official reports, AAPG Bulletin,

Branner, J. C., 1891. Introduction., in: Simonds, F. W., The Geology of Washington County, Arkansas. Geological Survey of Arkansas, Annual Report for 1888, IV: xi-xiv.

Cohen, K. M., Finney, S. C., Gibbard, P. L. and Fan, J.-X., 2013 [updated 2017] The ICS International chronostratigraphic chart. Episodes, 36, p. $199-204$.

Conybeare, W. D. and Phillips, William, 1822. Outlines of the Geology of England and Wales with an introductory compendium of the general principles of that science and comparative views of the structure of foreign countries, Part 1. William Phillips publisher, London, $563 \mathrm{p}$.

D’Omalius D’Halloy, J. B. J., 1853, Abrégé de géologie. Encyclopédic populaire, 3:271-400.

Gradstein, F. M., Ogg, J. G., and Smith, A. G., (eds.), 2004, A Geologic Time Scale 2004. Cambridge University Press, Cambridge, U.K., 589 p., 1 pl.

Gradstein, F. M., Ogg, J. G., Schmitz, M. D., and Ogg, G. M., (eds.), 2012, The Geologic Time Scale 2012. Amsterdam: Elsevier B V, 1143 p.

Kirwan, Richard, 1799. Essay VII, On Coal Mines, Geological Essays, T. Bensley, Holt Court, Fleet Street, London, p. $290-291$.

Munier-McHalmas, Ernest and de Lapparent, A. A. C., 1893. Note sur la nomenclature des terrains sédimentaires. Bulletin de la Societé Géologique de France, no. 3, p. 479-480.

Stevenson, J. J., 1888. D. Report of the subcommittee on the Upper Paleozoic (Carbonic) International Congress of Geologists, London Session. Reports of the subcommittee appointed by the American Committee from its own members, assisted by associates for the fourth session of the Congress to be held in London, September 17, 1888, p. D4-D7.

Williams, H. S., 1891. Correlation Papers - Devonian and Carboniferous. U. S. Geological Survey Bulletin 80, 1-279. Wilmarth, M. G., 1925. The geologic time classification of the United States Geological Survey compared with other classifications, accompanied by the original
definitions of era, period and epoch terms, U. S. Geological Survey Bulletin 729, 138 p. 